This article is distributed under the terms of the Creative Commons Attribution 3.0 PL (c) Copyright by Uniwersytet Warszawski Katedra Studiów Interkulturowych Europy

\title{
Lieux de Mémoire na pograniczu polsko-ruskim: przypadek ziemi chełmskiej (po 1863 roku)
}

W artykule podjęto analizę procesu unarodowienia Rusinów ziemi chełmskiej w okresie po powstaniu styczniowym. Od lat 50. XIX w. intelektualiści rosyjscy o orientacji słowianofilsko-panslawistycznej zaczęli postrzegać wschodnie kresy Królestwa Polskiego jako rdzennie rosyjskie ziemie. Tereny te, na skutek unii brzeskiej, były przez kilka stuleci pod silnym wpływem kultury polskiej i wyznania rzymskokatolickiego. Poprzez stosowanie takich narzędzi jak: muzea, prasa i publikacje apologetyczne dla szkoły i dla ludu, świętowanie jubileuszy wydarzeń państwowych i cerkiewnych, wznoszenie zabytków, renowacje cerkwi w stylu bizantyńskim (lieux de memoire), władza rosyjska dążyła do unarodowienia miejscowej ludności ruskiej. Wszystko to miało na celu zakorzenienie tożsamości rosyjskiej i prawosławnej. Większość lieux de mémoire została stworzona, wymyślona lub przerobiona, aby służyć państwu narodowemu. Owo „nostalgiczne doświadczenie" było sposobem kształtowania i kierowania świadomością historyczną. W ten sposób formowało się rosyjskie państwo narodowe, ustanawiające i legitymizujące się jako wielki proces odnowy oparty na pamięci i z niej stworzony. Wizję intelektualistów i duchowieństwa działających na kresach imperium można przedstawić w kategorii prymordializmu, a więc założenia, wedle którego naród jest definiowany jako grupa oparta na odwiecznej wspólnocie pochodzenia, religii i moralności, a także na przywiązaniu do ziemi ojców. Praktyka takiego nacjonalizmu peryferyjnego znacznie odbiegała od słynnej doktryny oficjalnej narodowości, sformułowanej przez Siergieja Uwarowa w latach 30. Żądania nacjonalistyczne z kresów imperium były z pewnością jednym z czynników, które doprowadziły do ewolucji polityki elit petersburskich w kierunku nacjonalizacji imperium Romanowów.

Słowa kluczowe: nostalgia, pamięć, nacjonalizm, Imperium rosyjskie, Królestwo Polskie 
Chełmszczyzna, czy też ziemia chełmska, historyczna kraina Królestwa Polskiego, znajdowała się w drugiej połowie XIX w. na wschodnich krańcach guberni lubelskiej. Aż do upadku imperium rosyjskiego w 1915 r. był to teren konfliktu między urzędnikami carskimi a elitą polską i katolicką o narodowy status miejscowego ruskiego i greckokatolickiego chłopstwa. Począwszy od lat 50. XIX w. ziemie te uznawano za rdzennie ( $a$ b origine) rosyjskie - w optyce nacjonalizmu rosyjskiego ${ }^{1}$ zostały one oderwane od pierwotnej rosyjskości i prawosławia przez trwającą kilka stuleci działalność polskiej szlachty i Kościoła katolickiego. Właśnie w tych latach, a szczególnie po powstaniu styczniowym, proces ,zbierania” ziem ruskich zmienił swój charakter.

Podczas rozbiorów przyłączone do imperium rosyjskiego tereny wschodnie Rzeczypospolitej zostały uznane za ziemie „przywrócone” (присоединенные, воссоединенные губернии) jako niegdyś należące do wotcziny (dziedzicznej własności) książąt ruskich, w tym przypadku do księcia Daniela Romanowicza (XIII w.). Zwolennikiem poglądu o carze rosyjskim jako prawowitym władcy tych terenów był N.M. Karamzin ${ }^{2}-$ oficjalny historiograf imperium, który usprawiedliwiał rozbiory Polski i przekonywał o słuszności utrzymania Królestwa Polskiego w granicach państwa rosyjskiego. W jego koncepcji podstawową rolę odgrywała kategoria więzi dynastycznej; dopiero później, pod wpływem ideologii słowianofilskiej, zaczęto spoglądać na kresy zachodnie imperium

\footnotetext{
${ }^{1}$ Nawiązujemy tu do teorii „,prymordializmu”, wedle którego „,[n]aród jest definiowany jako unikalna, spójna, wieczna i niezmienna grupa psychiczno-społeczna [...], oparta na wspólnocie pochodzenia, religii i moralności, a także na przywiązaniu do ziemi ojców”, M. Łuczewski, Odwieczny naród. Polak i katolik w Żmiącej, WN UMK, Toruń 2012, s. 87.

${ }^{2}$ Szerzej na ten temat zob. M. Piccin, Geografie wyobrażone rosyjskiego nacjonalizmu: gubernie zachodnie Imperium i „Ruś Chełmska” między tradycja a nowoczesnościa myśli narodowej, [w:] Przypominać zapomniane, odkrywać nieznane. Polskie losy - Kościót - Syberia - Rosja (XIX-XX w.): studia ofiarowane Profesorowi Eugeniuszowi Niebelskiemu $w$ 70. rocznice urodzin, red. nauk. Anna Barańska, Lublin 2019, s. 205-224; o Karamzinie por. np. M. Dąbrowska, P. Głuszkowski (red.), Mikołaj Karamzin i jego czasy, „Studia Rossica” XXIV/2017.
} 
jako ziemie zamieszkiwane przez Rusinów, czyli ludność wschodniosłowiańską i (niegdyś) prawosławną. Jednym z podstawowych założeń narracji rosyjskiego nacjonalizmu była więc konieczność „przywrócenia" Rusinowi - tj. ruskiemu chłopu - świadomości rosyjsko-prawosławnej. Sprzyjającą okazją do urzeczywistnienia tego zamierzenia stało się powstanie styczniowe, które urzędnikom i intelektualistom rosyjskim pozwoliło odkryć etnografię tych terenów. Po zlikwidowaniu w 1839 r. diecezji greckokatolickich na Litwie i Białorusi, w 1875 r. doszło do kasaty chełmskiej diecezji greckokatolickiej, czyli ostatniej pozostałości Unii w imperium. Przyczyny i skutki tego wydarzenia, jak i późniejszego ukazu o tolerancji z 1905 r., który spowodował, że byli unici wybrali masowo przejście do Kościoła katolickiego, zostały już szeroko omówione ${ }^{3}$. W dużo mniejszym stopniu uwagę badaczy przyciągało zjawisko rusyfikacji (unarodowienia) miejscowej ludności, będące częścią szeroko zakrojonego programu reform, wprowadzonych przez rząd carski w Królestwie Polskim po 1863 r., którym przyświecał cel „tworzenia Rosjan” w wymiarze etnowyznaniowym na obszarze ziemi chełmskiej.

W moim przekonaniu ów proces unarodowienia można (i trzeba) interpretować w kategoriach prymitywistycznej tęsknoty za wyidealizowaną przeszłością (w tym przypadku za prawosławną Rusią). Wedle ideologów tej koncepcji, element polski (szlachecki) i katolicki naruszył pierwotną równowagę państwową i religijną na dawnej Rusi. Urzędnicy rosyjscy, zaangażowani $\mathrm{w}$ reformy po powstaniu styczniowym, kierowali się więc ideą pamięci o dawnych czasach, stanowiącą w ich mniemaniu fundament, na którym miała opierać się identyfikacja człon-

${ }^{3}$ Th.R. Weeks, The «End» of the Uniate Church in Russia: The Vossoedinenie of 1875, „Jahrbücher für Geschichte Osteuropas”, 44(1)/1996, s. 28-40; A. Szabaciuk, „,Rosyjski Ulster”. Kwestia chetmska w polityce imperialnej Rosji w latach 18631915, Wydawnictwo KUL, Instytut Europy Środkowo-Wschodniej Lublin 2013; M. Piccin, La politica etno-confessionale zarista nel Regno di Polonia: la questione uniate di Cholm come esempio di nation-building russo (1831-1912), PhD Dissertation, Università Ca’ Foscari di Venezia, Venezia 2011. 
ków wspólnoty, który decydował też o jej przetrwaniu oraz o trwałości wspólnotowych więzi ${ }^{4}$. Idea wspólnoty „rosyjskiej i prawosławnej” miała zostać wskrzeszona i stać się źródłem narodowej identyfikacji ludności Chełmszczyzny. Nostalgia za „złotymi” czasami prawosławnej Rusi sprawiała, że dążono do odnawiania pamięci o miejscach, ludziach i zabytkach dawnej świetności.

Studium niniejsze, operując pojęciami pamięci i nostalgii, wpisuje się w nurt badań stosunkowo niedawnych (których potrzeba zrodziła się w wyniku głębokich przemian społecznych po drugiej wojnie światowej), zajmujących się miejscem nostalgii w narracji tożsamościowej zarówno politycznej, jak i historycznej, oraz rolą pamięci ${ }^{5}$ i związanej z nią emocjonalności. Kategorie te odgrywają ważną rolę w studiach antropologicznych i etnograficznych ${ }^{6}$, dotyczących przede wszystkim obszarów postsocjalistycznych i postkolonialnych, a więc ostatnich dziesięcioleci XX w. oraz pierwszych dekad obecnego stulecia. Bez wątpienia jednak tęsknotę za przeszłością, za statusem ante quo, można dostrzec również w mentalności społeczeństw wieku XIX - okresu, w którym głębokie i gwałtowne przemiany społeczne dokonane w wyniku upadku ancien

${ }^{4}$ I. Kabzińska, Pamięć, nostalgia i zazdrość o „,dawne, dobrze czasy”. Narracje i różne rodzaje pamięci, „Etnografia Polska”L(1-2)/2006, s. 177.

${ }^{5}$ Zob. fundamentalne dzieło P. Ricoeur, Pamięć, historia, zapomnienie, przeł. J. Margański, Universitas, Kraków 2007.

${ }^{6}$ Por. O. Angé, D. Berliner, Anthropology of nostalgia - anthropology as nostalgia, [w:] tegoż (eds.), Anthropology and Nostalgia, Berghahn Books, New York-Oxford 2015, s. 1-2; D. Berliner, The abuses of memory: Reflections on the memory boom in anthropology, ,, Anthropological Quarterly 78(1)/2005, s. 197-211; J. Winter, The generation of memory: Reflections on the "Memory Boom”, ,Contemporary Historical Studies, Archives \& Social Studies: A Journal of Interdisciplinary Research" 1(0)/2007, s. 363-397; J.V. Wertsch, Collective memory, [w:] Memory in Mind and Culture, eds. P. Boyer, J. V. Wertsch, Cambridge University Press, New York 2009, s. 117-137; J. Assmann, Collective memory and cultural identity, ,New German Critique" 65/1995, s. 125-133; A. Assmann, Cultural Memory and Western Civilization: Functions, Media, Archives, Cambridge University Press, New York 2011; F. Whitling, Damnatio memoriae and the power of remembrance. Reflections on memory and history, [w:] A European Memory? Contested Histories and Politics of Remembrance, New, eds. M. Pakier, B. Stråth, Berghahn Books, New York-Oxford, 2010, s. 87-97. 
régime'u oraz procesów modernizacyjnych stały się w historii Europy - centralnego punktu odniesienia dla Rosji ${ }^{7}$ - przełomem: czasem bolesnym i wywołującym silne emocje.

Romantyzm, który głęboko ukształtował świadomość pokolenia całej pierwszej połowy XIX w., zdecydowanie (i w jawnej opozycji do epoki oświecenia) odwrócił swe spojrzenie w przeszłość, w poszukiwaniu korzeni tożsamości w mityzowanej przeszłości. Nostalgia, tęsknota za tym, co utracone, wydaje się zatem częścią składową ideowego projektu nowoczesnego nacjonalizmu romantycznego. W epoce, w której ,przyśpieszanie historii” było bodźcem do poszukiwania tego, co było wcześniej, świadome kreowanie odczucia nostalgii nie stanowiło jedynie zabiegu pasywnego, retorycznego czy czysto estetycznego (tęsknoty dla tęsknoty), lecz było również aktywnym instrumentem, uwzględniającym zarówno cele retrospektywne, jak i prospektywne ${ }^{8}$; narzędziem stosowanym w celu obudzenia, rekonstrukcji i kształtowania tożsamości”. Chodzi tu zatem o nostalgię „pokrzepiającą”, która „próbuje dokonać ponadhistorycznej rekonstrukcji utraconego domu, [...] postrzega siebie jako prawdę i tradycję, [...] chroni za pomocą prawdy absolutnej, [...] ma centralne znaczenie dla najnowszych ruchów religijnych i narodowych"10. Nostalgia tego rodzaju pozwala na ukonstytuowanie się „pamięci narodu” definiującej jego tożsamość. W ten sposób pojmowana tęsknota za domem, określana także jako „powrót do domu”, do wyidealizowanej dawnej jedności, była silnie obecna w narracji rosyjskiego nacjonalizmu na kresach zachodnich Imperium rosyjskiego.

${ }^{7}$ Por. np. A. Nowak, Metamorfozy. Imperium Rosyjskiego 1721-1921. Geopolityka, ody i narody, Wydawnictwo Literackie, Kraków 2018; V. Strada, EuroRussia. Letteratura e cultura da Pietro il Grande alla rivoluzione, Laterza, Roma-Bari 2005.

${ }^{8}$ S. Boym, The Future of Nostalgia, Basic Books, New York 2001, s. xvii.

${ }^{9}$ N. Atia, J. Davies, Nostalgia and the shapes of history, „Memory Studies” 3(3)/2010, s. 182.

${ }^{10} \mathrm{~S}$. Boym, Nostalgia i postkomunistyczna pamięć, [w:] F. Modrzejewski, M. Sznajderman (red.), Nostalgia. Eseje o tęsknocie za komunizmem, Czarne, Wołowiec 2002, s. 270-301. Cyt. za: I. Kabzińska, Pamięć, nostalgia i zazdrość, s. 193. 
Dla carskich urzędników Królestwa Polskiego Chełmszczyzna stanowiła lieu de memoire (miejsce pamięci), lecz musiała również stać się milieu de memoire (środowiskiem pamięci) ${ }^{11}$. Tworzenie tego ostatniego polegało na unarodowieniu miejscowej ludności poprzez działalność rozszerzającą tożsamość rosyjską - carską i prawosławną. W tym celu potrzebne było wykreowanie nowej „odsłony” systemu symboli państwowości rosyjskiej i prawosławia, innymi słowy, reprodukcja przeszłości w teraźniejszość. Był to schemat myślenia wspólny dla nacjonalizmów dziewiętnastowiecznych: dawna rzeczywistość (państwowość) miała być, powrócić do bytu, ponieważ już kiedyś była; miała zostać ponownie zbudowana na fundamencie pamięci o dawnym, wspaniałym bytowaniu, zastępującym słabą teraźniejszość. Pamięć umożliwiała trwałość i ciągłość pomiędzy tym, co byto, co jest i co będzie $e^{12}$. Właśnie takim rozumowaniem kierował się jeden z urzędników rosyjskich, a zarazem protojerej cerkwi prawosławnej, Aleksandr S. Budiłowicz, w latach 1882-1885 opiekun Muzeum Cerkiewno-Archeologicznego w Chełmie oraz członek tamtejszego Prawosławnego Bractwa pw. Przenajświętszej Bogurodzicy ${ }^{13}$, zawzięty poszukiwacz

${ }^{11}$ Por. P. Nora, Les Lieux de mémoire, Gallimard, Paris, t. 1: La République (1 vol., 1984), t. 2: La Nation (3 vol., 1986), t. 3: Les France (3 vol., 1992); P. Nora, Between memory and history: Les Lieux de Mémoire, „Representations” 26/1989, s. 7-24; P. Ricoeur, Pamięć, historia, zapomnienie, zwłaszcza podrozdział: Pierre Nora: niezwykte miejsca pamięci, s. 533-545; P. Den Boer, Loci memoriae-Lieux de mémoire, [w:] Cultural Memory Studies. An International and Interdisciplinary Handbook, eds. A. Erll, A. Nuenning, W. de Gruyter, De Gruyter, Berlin-New York 2008, s. 21; M. Isnenghi, Italian luoghi della memoria, [w:] Cultural Memory Studies, s. 27; tenże (ed.), I luoghi della memoria. Simboli e miti dell'Italia unita, Laterza, Bari 1996; J. Winter, Historians and sites of memory, [w:] Memory in Mind and Culture, s. $252-268$.

${ }^{12}$ Por. M. Isnenghi, Italian luoghi della memoria, s. 27; M. Halbwachs, Les cadres sociaux de la mémoire, Albin Michel, Paris 1994 [1925], cyt. za : D. Berliner, The Abuses of Memory, s. 200.

${ }^{13}$ Profil biograficzny prawosławnego hierarchy zob. w: S. Dmitruk, Ks. Aleksander Budiłowicz (1845 - po 1914) - prawosławny duchowny z Grodzieńszczyzny w diecezji chetmskiej, [w:] Białorusini - Historia i kultura, red. J. Jurkiewicz, Expol, Szreniawa 2010, s. 127-136. 
wszelkich śladów rosyjskich starożytności (stariny) na Chełmszczyźnie. Był on wcieleniem ideału historyka-antykwariusza (łączącego przekaz piśmienny z interpretacją kultury materialnej i religijnej) $)^{14}$, entuzjastycznym pasjonatem starożytności, jednym z bohaterów złotej epoki przywłaszczania stariny w myśl rosyjsko-prawosławnej ,,sprawiedliwości historycznej" - procesu dokonywanego przez całą plejadę gorliwych działaczy, pochodzących przeważnie z zachodnich kresów imperium. Jak trafnie zauważył inny rosyjski czynownik Jewfimij Kryżanowski (także wywodzący się z prawosławnego duchowieństwa, działający w rosyjskiej szkole w Siedlcach), poczynaniami „odrodzicieli” świetnej przeszłości powodowało nie tylko chłodne, abstrakcyjne rozumowanie naukowe, lecz także „pulsująca ich rodzima krew”. Poważnym rozważaniom naukowym wtórowały więc często mityczne fantazje o utraconej przeszłości, co niekiedy skutkowało pseudonaukowymi teoriami. Kryżanowski o Aleksandrze Budiłowiczu pisał z nutą ironii: „On [Budiłowicz], by tak rzec, dmucha na każdą rodzimą kość wyciągniętą z grobów i próbuje ją uwiecznić" ${ }^{15}$. Przekonanie o roli mitotwór-

${ }^{14}$ Nawiązuję w tym miejscu do studiów Arnalda Momigliano i do zjawiska „metody antykwarycznej” (antiquarian method), zakładającej wykorzystanie w procesie tworzenia narracji historycznej źródeł nienależących do szeroko pojmowanej „literatury”, tzw. starożytności - „,antiquitates”: publicae, privatae, sacrae, militares”. W XIX w. doszło do swego rodzaju połączenia metody klasycznej z metodą antykwaryczną: coraz więcej historyków porównywało źródła literackie ze źródłami nieliterackimi, takimi jak epigrafika, numizmatyka, dyplomatyka. Co więcej, metoda ta weszła w tym samym czasie w swego rodzaju ,sojusz” z patriotyzmem lokalnym. Rozważania Momigliano o włoskiej historiografii XVIII i XIX w. dowodzą fundamentalnej roli poszukiwaczy starożytności w procesie kształtowania się europejskich nacjonalizmów na gruncie kultury romantycznej. Pisał Momigliano: „Several elements of the complex which made it possible for Foscolo to be an italian and for Leopardi to write his poetry can be traced back to museums, necropolises and learned societies". Szerzej na ten temat zob. A. Momigliano, Ancient history and the antiquarian, „The Journal of the Warburg and Courtauld Institutes" 13(3/4)/1950, s. 285-315, zwłaszcza s. 306-307. Por. też D. Nikulin, The Concept of History, Bloomsbury Academic, New York 2017, zwłaszcza rozdział „The epic of history”, s. 45-72.

${ }^{15}$ Е.М. Крыжановский, Речензия на сочинение магистра священника Александра Будиловича: Русская православная старина в Замостье, Варшава 1885 
czej i „majeutycznej” intelektualistów (dopomagali oni w narodzinach prawdy o narodowej świadomości ruskiego chłopa, za co należała się im z jego strony wdzięczność) oddanych dziełu wskrzeszenia dawno utraconego kolektywnego „my” widać w słowach, które Budiłowicz miał skierować do redaktora P.N. Batiuszkowa (byłego kuratora wileńskiego okręgu szkolnego i brata poety Konstantina), komentując bogato ilustrowaną serię wydawniczą Памятники русской старины в западных губерниях („Pomniki [Monumenta] rosyjskich starożytności w guberniach zachodnich") ${ }^{16}$ :

im dalej Ruś Chełmska będzie w sobie ową narodową samoświadomość rozwijać, tym jej poczucie wdzięczności za takie wspaniałe wydania zabytków jej stariny silniejsze będzie dla tych ludzi, dzięki którym ziemia ta otrzymała taki dar na pamięć i pouczenie (z przeszłości dla teraźniejszości i ku przyszlości) [wyróżnienie - M.P.] ${ }^{17}$.

Instrumentami działań „narodowotwórczych”, czyli projektu unarodowienia Rusinów, stały się muzea, prasa, publikacje apologetyczne dla szkół i dla ludu, o charakterze zarówno naukowym, jak i popularnonaukowym, którym towarzyszyły inne, równie istotne działania: m.in. celebracje rocznic dawnych wydarzeń państwowych i cerkiewnych, odbudowa zabytków i ceremonie ich otwarcia. Wszystkie te elementy kształtowania świadomości narodowej składają się na zbiór tekstów

года. Отчет о тридиатом присуждении наград графа Уварова, тип. Акад. наук, , Санкт-Петербург1889, s. 3-4, 6.

${ }^{16}$ Памятники русской старины в западных губерниях, издаваемые с высочайшего соизволения П.Н. Батюшковым, Вып. 7: Холмская Русь (Люблинская и Седлецкая губ., Варшавского Генерал-Губернаторства), М-во внутр. дел, Санкт-Петербург 1885; Вып. 8: Холмская Русь (Люблинская и Седлецкая губ., Варшавского Генерал-Губернаторства), М-во внутр. дел, Санкт-Петербург 1885. Warto zauważyć stosowanie terminu памятники (od „память”), tj. pomniki (od „pamięć”), łac, monumenta (od „monere”, pamiętać) - wszystkie odsyłają etymologicznie do kluczowego dla naszych rozważań słowa ,pamięć”.

${ }^{17}$ Отдел Рукописей Российской Национальной Библиотеки [ОР РНБ], ф. 52, ед. хр. 132, л. 5. 
mediacji kulturowej ${ }^{18}$, które nazwać tu należy miejscami pamięci (lieux de memoire), powtarzającymi się motywami (loci communes) - topoi rosyjskości na Chełmszczyźnie. Będę tu omawiać ich kilka, a mianowicie: wieże pod Chełmem w Stołpiu i Bieławinie, ikonę Matki Boskiej Chełmskiej, postać księcia Daniela Romanowicza (Halickiego). Wiedza na temat tych obiektów była popularyzowana dzięki działalności chełmskich instytucji, takich jak np. Bractwo Przenajświętszej Bogurodzicy i Muzeum Cerkiewno-Archeologiczne ${ }^{19}$.

\section{Wieże w Stołpiu i Bieławinie}

Od lat 60. XIX w. historyczna obecność państwowości ruskiej na pograniczu polsko-ruskim zaczęła przyciągnąć uwagę historyków i filologów-slawistów należących do młodego pokolenia naukowców. Byli oni uczniami „ojców rosyjskiej slawistyki”, szczególnie I. I. Sriezniew-

${ }^{18}$ M. Tamm, Beyond History and Memory: New Perspectives in Memory Studies, „History Compass” 11(6)/2013, s. 461.

${ }^{19} \mathrm{Z}$ powodu ograniczonych rozmiarów obecnego artykułu, nie sposób omawiać wszystkich miejsc i struktur pamięci działających na ziemi chełmskiej. W kwestii np. czytelnictwa jako narzędzie unarodowienia chłopa małoruskiego odsyłamy do niedawnych studiów M. Przeciszewskiej: Tygodnik Ilustrowany „Oświata” jako narzędzie formowania ,cesarskiego chłopa” w Królestwie Polskim w latach 1900-1905, „Rocznik Biblioteki Narodowej” XLVI/2015, s. 197-219; „Tworzenie Rosjan”. Narodowotwórcza funkcja wybranych publikacji Bractwa Przenajświętszej Bogurodzicy w Chetmie (1884-1915), „Rocznik Biblioteki Narodowej” XLVIII/2017, s. 347-372. O muzeum jako strukturze instytucjonalizującej pamięć par excellence, zob. np. M. Pickering, E. Keightley, The modalities of nostalgia, „Current Sociology” 54/2006, s. 919-941; J. Kindt, On nostalgia, „Meanjin” 77(2)/2018, s. 199-205; P. Aronsson, G. Elgenius (eds.), National Museums and Nation-Building in Europe 1750-2010: Mobilization and Legitimacy, Continuity and Change, Routledge, New York 2015; F. Bellentani, M. Panico, The meanings of monuments and memorials: toward a semiotic approach, „Punctum” 2(1)/2016, s. 28-46. O zbieraczach, kolekcjonerach i narodzinach muzeów zob. K. Pomian, Zbieracze i osobliwości. ParyżWenecja XVI-XVIII wiek, przeł. A. Pieńkos, słowo/ obraz terytoria, Gdańsk 2012, zwłaszcza s. 48-61. 
skiego i O.M. Bodianskiego ${ }^{20}$ lecz od swych poprzedników odróżniali się nowym ujęciem historii imperium rosyjskiego w perspektywie słowianofilstwa i panslawizmu. Ich wizja historii nie była pozbawiona nuty szowinizmu: odkrycie stariny w latach 30 . i 40., charakteryzujące się podejściem stricte naukowym lub najwyżej patriotycznym, przybrało w ich ujęciu zabarwienie typowo nacjonalistyczne. Pośród namacalnych zabytków rosyjskich starożytności pogranicza, najczęściej ruin, specyficzne miejsce zajmowały (obok cerkwi) fortyfikacje obronne - zazwyczaj odizolowane wieże, usytuowane wzdłuż niestabilnych granic między księstwami ruskimi a Litwą i Polską. Przykład ponownego odkrycia jednej z tych wież i rosyjskiej stariny ziemi grodzieńskiej można odnaleźć w korespondencji młodego Antona S. Budiłowicza wówczas studenta Uniwersytetu w Petersburgu, w latach 80. slawisty na Cesarskim Uniwersytecie Warszawskim, w następnej dekadzie zaś rektora Uniwersytetu w Dorpacie), brata wspomnianego Aleksandra, z I.I. Sriezniewskim. Budiłowicz pragnął zapoznać swojego mistrza z wynikami letnich badań terenowych, przeprowadzonych w 1864 r. na jego ziemi ojczystej (Budiłowicz pochodził z Grodzieńszczyzny). Młody slawista przedstawiał miasto Kamieniec i zwracał szczególną uwagę na wieżę (Каменецкая вежа lub столб, lub jeszcze столn w miejscowym wariancie, zob. rys. 1), na nieobecność dawnych cerkwi oraz opłakany stan tych jeszcze istniejących, przekształconych po unii brzeskiej w kościoły unickie. Godny uwagi jest tu wymiar emocjonalny słów zapalonego studenta ${ }^{21}$. Oprócz gorliwości w odkrywaniu korzeni, aspektem, który odróżniał postawę młodszego pokolenie naukowców od stanowiska ich nauczycieli, było

\footnotetext{
${ }^{20}$ Por. np. Н. Найт, Наука, империя и народность: этнография в Русском географическом обществе, [w:] Российская империя в зарубежной историографии. Работы последних лет: Антология, Сост. П. Верт, П.С. Кабытов, А.И. Миллер, Новое издательство, Москва 2005, s. 155-198; Л.П. Лаптева, История славяноведения в России в XIX веке, Индрик, Москва 2005.

${ }^{21}$ Wiadomo skądinąd, że romantyczny topos ruiny i rustykalnej wioski jest cechą wszechobecną w literaturze i kulturze romantycznej. Por. N. Atia, J. Davies, Nostalgia and the shapes, s. 182.
} 


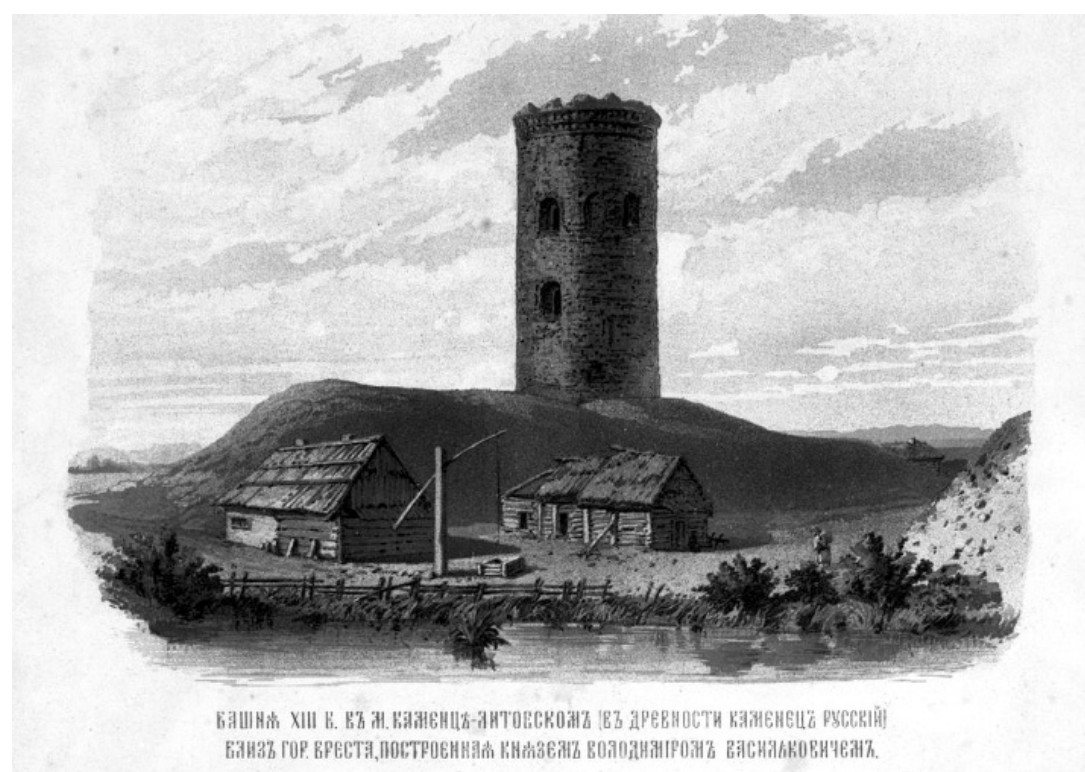

Rys. 1. Wieża w Kamieńcu lub też Biała wieża (źródło: Памятники русской старины в западных губерниях, издаваемые с высочайшего соизволения П.Н. Батюшковым, [Альбом], Вып. 8: Холмская Русь, М-во внутр. дел, Санкт-Петербург. 1885, ze zbiorów cyfrowych Rosyjskiej Państwowej Historycznej Biblioteki Publicznej)

właśnie pragnienie przywrócenia „sprawiedliwości historycznej” po długoletnim obcym panowaniu. List Budiłowicza, ubolewającego nad losami ojczyzny, kończył się znamienną uwagą: „oto tutaj właściwa starina: pozostałości starożytnego prawosławia w tutejszym kraju"22.

$\mathrm{Na}$ terenie guberni lubelskiej znajdowały się dwie wieże przypominające opisywaną przez Budiłowicza kamieniecką. W narracji rosyjskiego nacjonalizmu stały się one jednym z najczęściej wykorzystanych symboli dawnej państwowości ruskiej. Ich reprodukcje były obecne w niemal wszystkich opublikowanych po 1863 r. tekstach na temat

${ }^{22}$ И.И. Срезневский, Каменеикая вежа, [w:] Онже, Сведения и заметки о малоизвестных и неизвестных памятниках, вып I, тип. Императорской Академии Наук, С.-Петербург 1867, s. 8. 
rosyjskości tego regionu, zarówno naukowych, jak i popularnonaukowych. Rzeczywista funkcja tych obiektów do dziś stanowi przedmiot sporu wśród naukowców ${ }^{23}$. Wieża w miejscowości Stołpie (rys. 3) stoi w odległości $8 \mathrm{~km}$ od Chełma, wzdłuż drogi ekspresowej S12 łączącej Radom z Dorohuskiem i przebiegającej przez Lublin oraz sam Chełm; natomiast wieżę w Bieławinie (wówczas wsi pod Chełmem, rys. 2), która już w XIX w. znajdowała się w stanie ruiny (składała się tylko z jednej ściany), zburzono podczas okupacji niemieckiej w 1944 r. Spośród licznych świadectw refleksji, które rosyjscy urzędnicy i naukowcy poświęcili tym budowlom, wyszczególnię te najdobitniej eksponujące ich znaczenie symboliczne dla nacjonalizmu rosyjskiego.

Fieofan Gawriłowicz Lebiedincew, były student i wykładowca w Akademii Teologicznej w Kijowie, popowicz (syn prawosławnego duchownego) rozmiłowany w tradycjach i obyczajach ludu wiejskiego i prawosławia, został mianowany przez F.F. Wittego, dyrektora Komisji ds. oświaty ludowej w Królestwie Polskim na dyrektora szkół w Chełmie, które sprawował w latach 1865-1871. Opuszczając Chełm w 1871 r., by objąć posadę dyrektora szkoły w Radomiu, Lebiedincew został odprowadzony przez delegację chełmskich urzędników i uczniów do Stołpia. Miał wówczas rzec: „Oto tysiącletnia wieża! Tu bez wątpliwości przebiegała granica ziemi i osiedleń rosyjskich. Jadę do Polski,.. Przy tej samej okazji rosyjski czynownik życzył sobie, aby w procesie nacjonalizacji imperium, przesunięto jeszcze bardziej na zachód „magiczną” (sic!) granicę świata rosyjskiego ${ }^{24}$. Wypowiedź ta jest wielce charakterystyczna, pokazuje bowiem, że naukowemu podejściu do pozostałości po Rusi Chełmskiej towarzyszył element irracjonalny, romantyczny czy wręcz magiczny.

${ }^{23}$ Najbardziej prawdopodobna była ich funkcja obronna, jednak wysuwane są też hipotezy o ich roli rezydencjalnej, myśliwskiej bądź sakralnej. Por. A. Buko, Zagadka pogranicza. Zespót wieżowy w Stotpiu, „Archeologia Żywa” 3(33)/2005, s. 44-49 i tenże (red.), Zespół wieżowy w Stołpiu: badania 2003-2005, IAE PAN, IA UW, Warszawa 2009.

${ }^{24}$ Національна бібліотека України імені В. І. Вернадського, Інститут рукопису (IP НБУВ), ф. I (Лебединцев Феофан Гаврилович), н. 11169, Материальг к биографии Ф.Г. Лебединиева, кк. 14-15. 
Opublikowany w „Chełmskim Kalendarzu Greckokatolickim”25 w 1868 r., artykuł autorstwa P. Riewiakina ${ }^{26}$ szeroko omawiał pochodzenie, etymologię oraz cechy architektoniczne dwóch wież. Autor podkreślał, że ludowa nazwa wsi „Stołp” bezpośrednio nawiązywała do jej wschodniosłowiańskiego pochodzenia. Miało to utwierdzić

w ówczesnych Rusinach niezależność zasady rosyjsko-słowiańskiej, która, w późniejszej epoce, pod presją polskiej szlachty i duchowieństwa rzymsko-katolickiego, zostało wypaczone w obyczajach i tradycjach a także w języku, dziś fonetycznie zmienionym przez wpływ idiomów polskiego i mazurskiego: dziwnie brzmi w ustach spolszczonego ludu wyraz „stołp”, słowo pachnące Rusią, wtedy kiedy termin ten został zastąpiony, w codziennym użyciu, polskim ,słup"27.

Powołując się na tekst Phoenix redivivus albo obraz starożytny chetmski Panny i Matki Przenajświętszej (Zamość 1646), słynne dzieło chełmskiego biskupa greckokatolickiego Jakuba Suszy, Riewiakin zwracał uwagę na zakorzenione wśród miejscowej ludności legendy o powstaniu wieży. Miejscowi chłopi byli przekonani, że budowa zo-

${ }^{25}$ Ludowy kalendarz Холмский греко-униатский Месяцеслов był swego rodzaju almanachem, zawierającym, obok tekstów apologetycznych o historii i kulturze rosyjsko-prawosławnej, wiele przydatnych informacji dla ludności chłopskiej, jak np. dane o fazach księżyca, terminy jarmarków czy świąt kalendarza prawosławnego i państwowego, a także informacje dot. Rodziny Carskiej. O almanachu - książce par excellence dla ludu - i jego roli w tworzeniu tożsamości narodowej ludności wiejskiej zob. E. Weber, Da contadini a francesi. La modernizzazione della Francia rurale 1870-1914, Il Mulino, Bologna 1989, s. 847-851 (Por. wydanie oryginalne w języku angielskim: Peasants Into Frenchmen: The Modernization of Rural France, 1870-1914, Stanford, Stanford University Press, 1976).

${ }^{26}$ Столпы или вежи под Холмом (Из записок П. Ревякина), „Холмский греко-униатский Месяцеслов на 1868 год”, Варшава 1868, s. 129-142. O wieżach w Stołpiu i Bieławinie w ujęciu ,poszukiwaczy” starożytności zob. też Ф. Гербачевский, Русские древности и памятники православия Холмско-Подлямской Руси (Люблинской и Седлечкой губернии), Сочинение и издание любителя Русской Старины священ. Федора Гербачевского, Варшава 1892, s. 24-25, 27-30.

${ }^{27}$ Столпы или вежи под Холмом, s. 137-138. Por. odmienne stanowisko polskich polemistów: H. Wiercieński, Ziemia Chetmska i Podlasie. Rys historyczny i obraz stanu dzisiejszego, Gebethner i Wolff, Warszawa 1920, s. 4-7. 


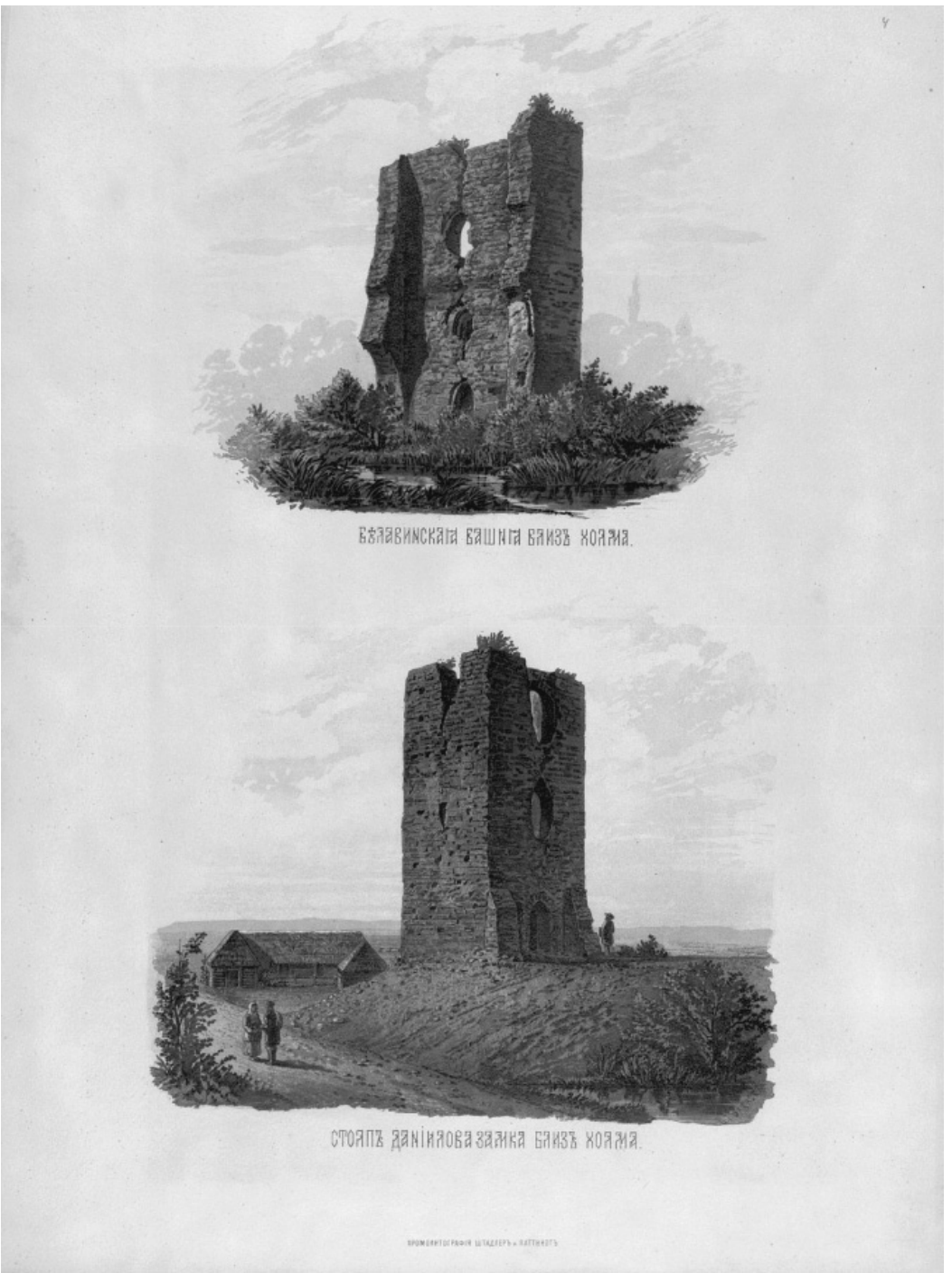

Rys. 2-3. Wieża w Bieławinie i Stołpiu (źródło: Памятники русской старины в западных губерниях, издаваемые с высочайшего соизволения П.Н. Батюшковым, [Альбом], Вып. 7: Холмская Русь, М-во внутр. дел, Санкт-Петербург. 1885, ze zbiorów cyfrowych Rosyjskiej Państwowej Historycznej Biblioteki Publicznej) 
stała wzniesiona za sprawą księcia Polan wschodnich - legendarnego Szczeka, który miejsce to, obfitujące w zwierzynę w pobliskich lasach, przeznaczyć miał na polowania.

Kolejne uwagi o chełmskich wieżach odnajdujemy w VII tomie już wymienionych Pomników rosyjskich starożytności na Rusi Chetmskiej. Autor tekstu G.K. Chruscewicz, syn prawosławnego duchownego, czynnie zaangażowany $\mathrm{w}$ zakorzenianie prawosławia $\mathrm{w}$ regionie po $1875 \mathrm{r}$., przytaczał opinie innych naukowców o niezwykle ważnej roli obronnej stołpieńskiej wieży jako jednego z elementów systemu fortyfikacyjnego założonego wzdłuż granicy między Rusią a Polską ${ }^{28}$. Jego zdaniem długa niepamięć o wieżach chełmskich $\mathrm{w}$ ruskich latopisach miała oznaczać, że obiekty w rzeczywistości miały pełnić nie tyle funkcję obronną, ile raczej rezydencji ruskiego księcia, który (co już wiadomo z tekstu Riewiakina) miał wybrać te strony $\mathrm{z}$ racji na bogactwo zwierzą $\mathrm{t}^{29}$. Owym ruskim księciem był ze wszelkim prawdopodobieństwem już wspomniany Szczek, którego legenda zyskiwała wymiar historyczny. Dowodzenie „rosyjskości” tego regionu miało więc charakter mitotwórczy, sięgając jeszcze dalej niż czasów ruskich księstw i ginąc w pomroce dziejów: Chełm był rosyjski ab origine, mit i historia łączyły się w jedno.

\section{Ikona Matki Boskiej Chełmskiej}

Zgodnie z tradycją ikona Matki Boskiej Chełmskiej (rys. 4) ${ }^{30}$ została napisana przez św. Łukasza i oferowana miastu przez Św. Wło-

${ }^{28}$ Е.М. [Модест, епископ], Холмская православная епархия. Город Холм, „Холмско-Варшавский епархиальный вестник” 4/1884, s. 53-59. Autorstwo przypisane biskupowi Modestowi na podstawie ОР РНБ, ф. 52, ед. хр. 185, л. 25.

${ }^{29}$ Г.К. Хрусцевич, Белавинская и Столпьенская башни под Холмом, [w:] Памятники русской старины, Вып. 7, s. 60-62.

${ }^{30}$ А.С. Будилович, Чудотворная икона Пресвятой Богородицы в г. Холме, [w:] Памятники Русской старинь, s. 63-112. Dzieło to później przedrukowano w rozszerzonej wersji: А. Будилович, Холмская чудотворная икона Божией Матери, тип. Варшавскаго учебного округа: издание Холмскаго Св. Богородицкаго братства, Варшава 1892; Ливотов, Е.В., Краткое сказание о Холмской чудотворной 
dzimierza $^{31}$. Inne źródła podają, że ikonę sprowadzono do Chełma za sprawą Daniela Romanowicza i od tego momentu obraz był przechowywany w Chełmskiej katedrze. Stał się on obiektem kultu wielowiekowej dewocji oraz jednym z symboli, które służyły Cerkwi prawosławnej do prowadzenia dzieła „rewitalizacji” dawnego prawosławia. Między 1874 a 1878 r., podczas gruntownych prac remontowych katedry w celu usunięcia „naleciałości” łacińskich i przywrócenia jej pierwotnego wyglądu bizantyńskiego, ikona znalazła się w cerkwi św. Mikołaja w Chełmie. Po ukończeniu restauracji świątyni obraz ponownie przeniesiono do soboru i umieszczono nad carskimi wrotami jako centralny element nowego ikonostasu. W 1891 r. przykryto go nową ryzą, wykonaną według kanonu staroruskiego; poświęcenie i nałożenie nowej szaty miało miejsce 8 września tegoż roku, w obecności głównych hierarchów Cerkwi prawosławnej w tej części imperium; stara sukienka Matki Boskiej oraz Dzieciątka, pochodząca z 1660 r., stała się eksponatem chełmskiego Muzeum Cerkiewno-Archeologicznego jako ozdoba do nowo wykona-

иконе божией матери и бывших от нее чудесах, Холмск. св. Богородиц. братство, Холм 1899; Ф. Гербачевский, Русские древности и памятники православия Холмско-Подляшской Руси, s. 21-23. Literatura na temat tej ikony, por. J. Stefański, Z dziejów kultu obrazu Matki Boskiej Chetmskiej, „Nasza Przeszłość. Studia z dziejów Kościoła i kultury katolickiej w Polsce" 66/1986, s. 159-190; A. Gil, Geneza nowożytnego kultu ikony Matki Boskiej Chetmskiej, [w:] Волинська ікона: дослідження та реставраиія, вип. 10, Матеріяли Х міжнародної наукової конференції, Луцьк 2003, s. 106-112.

${ }^{31}$ Por. Путь моей жизни. Воспоминания Митрополита Евлогия. Изложенные по его рассказам Т. Манухиной, YMCA-PRESS, Париж 1947, s. 94. Autor tych notatek, Eulogiusz, był najpierw rektorem chełmskiego seminarium duchownego, więc od 1905 r. biskupem chełmskim i lubelskim. Jako poseł do rosyjskiej Dumy, był głównym pomysłodawcą utworzenia guberni chełmskiej i przyłączenia jej do imperium rosyjskiego. W swoich pamiętnikach, Eulogiusz podkreślał autentyczność i wiek ikony, opierając się na badaniach przeprowadzonych przez rosyjskiego akademika A.I. Sobołewskiego, członka Cesarskiej Akademii Nauk, które potwierdziły, że ikona szczyciła się greckim pochodzeniem i powstała w IX-X w. Eulogiusz podkreślał ponadto, że według historycznego podania, założycielem Chełma miał być ten sam ks. Włodzimierz. Podczas polowania książę zabłądził i natknął się na miejsce, które tak mu się spodobało, że zdecydował się na budowę nowego grodu. 
nej kopii ikony, którą wystawiono w sali, gdzie zbierało się Bractwo Przenajświętszej Bogurodzicy.

Z okazji święta Matki Boskiej Chełmskiej, przypadającego na 8 września, pielgrzymi udawali się thumnie do chełmskiego soboru. W celu rozszerzenia kultu tego obrazu, władze rosyjskie udzielały pielgrzymom ulg, by ułatwić pokonanie czasem znaczących odległości. Wiernych pochodzących nawet $\mathrm{z}$ oddalonych miejscowości w głębi Rosji zachęcano do udziału w takich przedsięwzięciach ${ }^{32}$. Pielgrzymki były narzędziem spajania prawosławnego ludu w poczuciu jedności nie tylko wyznaniowej, lecz także narodowej. Chełm wraz z jego cudowną ikoną znalazł się zatem w panteonie rosyjskich miast, w których czczono obrazy Matki Boskiej, wraz z Matką Boską Włodzimierską, przechowywaną w Moskwie, Matką Boską Kazańską - w Petersburgu, Poczajowską, a także Częstochowską i Ostrobramską. W narracji rosyjskiego nacjonalizmu ostatnie dwa wizerunki na równi z pozostałymi ikonami stanowiły wspólne dziedzictwo prawosławia, lecz przez zmienne losy historii stały się kością niezgody między katolicką Polską a Rosją. Fakt ten podkreślał wspomniany dyrektor szkół chełmskich Fieofan Lebiedincew, zaznaczając, że częstochowska i ostrobramska ikona wciąż pozostają w polskich rękach ${ }^{33}$.

W apologetyce prawosławnej po 1875 r. istnieje kilka pozycji poświęconych chełmskiej ikonie i jej roli w ludowej pobożności. Na przykład w roku 1882 w czasopiśmie „Chołmsko-Warszawski Jeparchialny Wiestnik" ukazał się historyczny esej, wydany również jako oddzielna

${ }^{32}$ J. Stefański, Z dziejów kultu obrazu Matki Boskiej Chetmskiej, s. 171-172. Por. О.П., Замечательный праздник в г. Холме, „Киевская старина” 11/1886, s. 561567; Путь моей жизни, s. 144-145; Ю.А. Лабынцев, Л.Л. Щавинская, Живая древность: литературная традиии культа иконы Богоматери Холмской наших дней, „Древная Русь. Вопросы медиевистики” 2(8)/2002, s. 14-25.

${ }^{33}$ B.М., Город Холм и его древняя святыня чудотворная икона Божией Матери, Издание Холмско-богородицкого православного братства, Варшава 1882, s. 13; por. Холмский Братчик [Ф.Г. Лебединцев], (recenzja) Город Холм и его древняя святыня - чудотворная икона Божией Матери, Издание Холмско-богородицкого православного братства, Варшава 1882, „Киевкая старина” 3/1883, s. 653-657. 


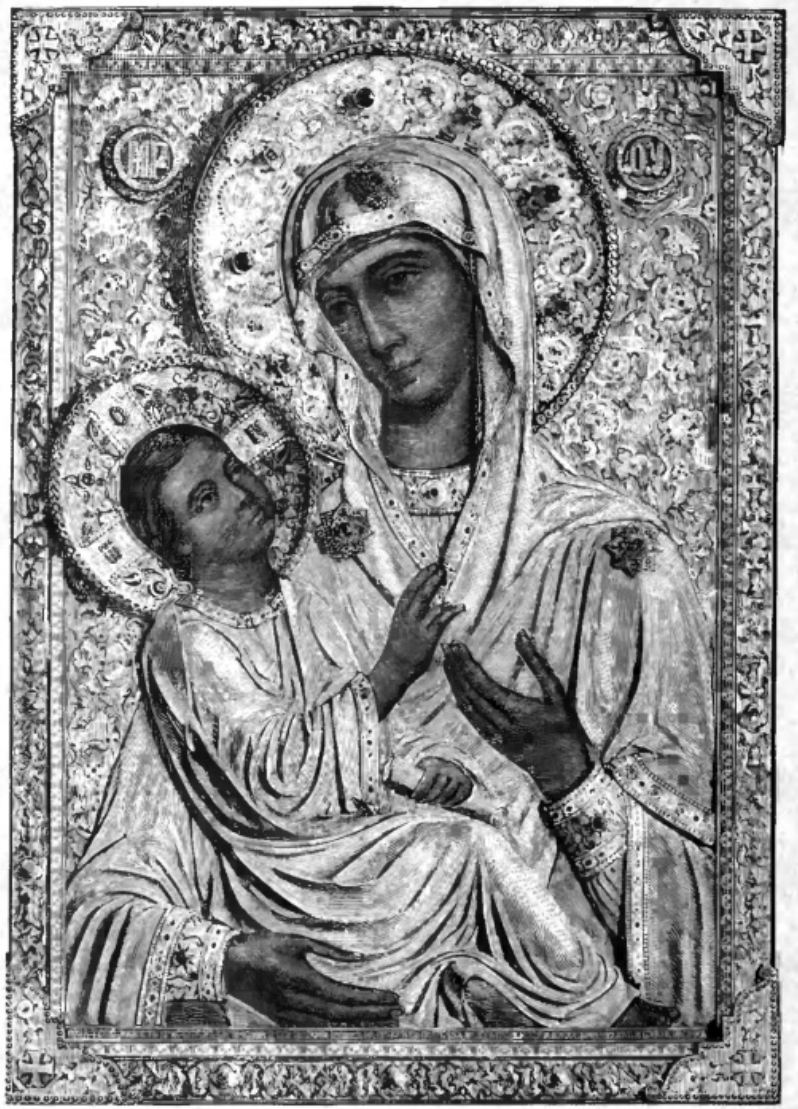

Холмская чудотворная икона.

Rys. 4. Ikona Matki Boskiej Chełmskiej (źródło: А.С. Будилович, Холмская чудотворная икона Божией Матери, тип. Варшавскаго учебного округа: издание Холмскаго Св. Богородицкаго братства, Варшава 1892, ze zbiorów cyfrowych Wojewódzkiej Biblioteki Publicznej im. Hieronima Łopacińskiego w Lublinie) 
odbitka pod redakcją Bractwa Przenajświętszej Bogurodzicy ${ }^{34} \mathrm{w}$ formie zwięzłej przystępnej broszury, wydrukowanej w nakładzie 3000 egzemplarzy. Wydanie to skierowane było bezpośrednio do prawosławnych wiernych i kolportowane bezpłatnie. Zawierało krótką rozprawę historyczną o świętym obrazie i mieście Chełm, zaopatrzoną w materiał ikonograficzny z przedstawieniami ikony, chełmskiego soboru oraz popularny widok miasta z XVII w. i wieży w Stołpiu i Bieławinie.

Ikonie Matki Boskiej Chełmskiej poświęcone zostało poza tym treściwe studium autorstwa Aleksandra Budiłowicza, opublikowane we wspomnianej serii Памятники русской старины. Z tego opracowania wyłonimy niektóre wątki ważne dla naszych rozważań. Zdaniem rosyjskiego duchownego, ikona nosiła w sobie nie tylko wartość duchową; miała również wymiar czysto polityczny, była znakiem przywrócenia na Chełmszczyźnie dawnego układu politycznego i cerkiewnego, rosyjsko-prawosławnego.

Jeszcze w dawnych czasach cudotwórczy obraz Matki Boskiej Chełmskiej, obecnie przechowywany w Soborze Najświętszej Maryj Panny, jest przedmiotem otaczanym niezwykłą czcią w mieście Chełm i w całym regionie, i jest bardzo znany również daleko poza jego granicami. Ta święta ikona i Sobór są cennymi drogowskazami w życiu politycznym i religijnym rosyjsko-prawosławnej stariny $w$ tym regionie po tej stronie Bugu. Są one miarą rzeczywistej wagi przeszłości Rusi chełmskiej i w odniesieniu do nich nabiera kształtu obecne znaczenie miasta, a przez nie i całej Chełmszczyzny i Podlasia ${ }^{35}$.

Ze względu na brak danych w ruskich latopisach, głównym źródłem do rozważań na temat tego toposu było dla Budiłowicza słynne opracowanie biskupa Jakuba Suszy, zawierające historię obrazu ${ }^{36}$. Za

${ }^{34}$ В.М., Город Холм и его древняя святыня чудотворная икона Божией Матери, Издание Холмско-богородицкого православного братства, Варшава 1882.

${ }^{35}$ А.С. Будилович, Чудотворная икона, s. 62. Por też Ливотов, Е.В., Краткое сказание.

${ }^{36}$ Por. K. Mart, ,Phoenix” Jakuba Suszy źródlem do badań ikonografii Matki Boskiej Chetmskiej, „Series Byzantina” 2/2004, s. 189-201. 
biskupem, rosyjski autor potwierdził tezę bizantyńskiego pochodzenia ikony, lecz przy tym zwrócił uwagę, że Susza jako mnich bazyliański nie mógł troszczyć się o przeszłość prawosławną Chełma sprzed unii brzeskiej; Budiłowicz, natomiast, przekonywał, że przed „narzucaniem” unii, chełmska ikona „,w ludowym wyobrażeniu i przekonaniu uczyła i chroniła zasady rosyjsko-prawosławne wierne rosyjskiej starinie; poprzez najskromniejsze oddawanie jej czci, cała Ruś Chełmska łączyła się w jedności wiary i miłości”37.

Po zawarciu unii brzeskiej - dowodził dalej Budiłowicz - rozpoczął się dłuższy okres upadku żywiołu rosyjsko-prawosławnego, w jego podwójnej postaci: narodowej oraz wyznaniowej. Odpowiedzialni za zaistniałą sytuacją byli przede wszystkim niektórzy chełmscy biskupi, szczególnie już wspomniany Jakub Susza, który miał zniesławić się odebraniem ikony prawosławnym wyznawcom (w połowie XVII w. jeszcze dość liczebnym) i przekazaniem jej królowi Janowi Kazimierzowi. Polacy zaś nosili ten obraz ze sobą, prosząc o wstawiennictwo podczas wojen kozackich. Kolejni biskupi po Suszy nie tylko byli winni propagowania Unii w wymiarze dogmatycznym i liturgicznym, lecz także gruntownym przekształceniom i latynizacji kościoła katedralnego w Chełmie. Liczne renowacje i odbudowy, przeprowadzone przede wszystkim w XVIII w. ${ }^{38}$, w opinii rosyjskiego duchownego nie zaspokajały autentycznych potrzeb chełmskiej eparchii, miały tylko kształtować zbiorową wyobraźnię Rusinów, zakorzeniając w nich świadomość wspólnoty wiary z Rzymem. Jeszcze jednym wydarzeniem o wysokim znaczeniu symbolicznym dla ludności greckokatolickiej, wspomnianym przez Budiłowicza i innych apologetów rosyjsko-prawosławnych, była koronacja ikony Matki Boskiej Chełmskiej. Święto miało miejsce 15 września 1765 r. i towarzyszył mu niezwykle bogaty program nabo-

\footnotetext{
${ }^{37}$ А.С. Будилович, Чудотворная икона, s. 79-80.

${ }^{38}$ Jak wiadomo, w 1720 odbył się sobór w Zamościu, który przesądził dalszą latynizację obrzędu greckokatolickiego.
} 
żeństw, przemówień, a nawet fajerwerków ${ }^{39}$. Budiłowicz kończył swój esej, wspominając o niedawnych wydarzeniach, które dotyczyły ikony i soboru, a mianowicie o likwidacji unii w 1875 r. i pracach remontowych przeprowadzonych w latach 1874-1878. Przebudowa katedry miała nadać świątyni wygląd zgodny z tradycyjną architekturą rosyjską, co pozwoliłoby zbudować pomost łączący wspólnotę rosyjskich prawosławnych z Chełma z ich przodkami oraz braćmi z całej Rosji.

Doniosłe znaczenie ikony jako symbolu ciągłości rosyjsko-prawosławnej na Chełmszczyźnie potwierdza fakt, że w 1887 r. wraz z publikacją książki Холмская Русь $^{40}$, która stanowiła uproszczoną i bardziej przystępną dla wiernych wersję dwutomowych „Pomników”, wydrukowano równocześnie 10 tys. egzemplarzy reprodukcji obrazu Matki Boskiej Chełmskiej. Podobnie jak w przypadku innych publikacji skierowanych do ludu obrazy te miały być rozdawane wiernym za sprawą takich instytucji jak Bractwo Przenajświętszej Bogurodzicy. Redaktor tomu P.N. Batiuszkow podkreślał, że chełmski wizerunek Matki Boskiej był otaczany wielką czcią na ziemiach ruskich, a także poza granicami imperium: w Galicji, Bukowinie, Rusi Zakarpackiej i ogólnie na terenie całej Słowiańszczyzny ${ }^{41}$. W ówczesnej narodowej myśli rosyjskiej ikona, stanowiła zatem symbol jedności wyznaniowej wszystkich ziem uważanych za irredentę rosyjską. Innymi słowy, obraz jednoczył geografie wyobrażone nacjonalizmu rosyjskiego

\section{Książę Daniel Romanowicz, „król” Rusi}

Kolejnym i ostatnim w naszym studium lieu de memoire, powracającym w apologetyce i w rosyjskiej narracji mitotwórczej po $1863 \mathrm{r}$.

${ }^{39}$ Por. np. Ф.Г. Лебединцев, Открытие в г. Холме русской седмиклассной гимназии и педагогических курсов, „Киевские епархиальные ведомости” 21/1865, s. $815-816$.

${ }^{40}$ [Н.И. Петров], Холмская Русь. Исторические судьбы русского зарубежья, Изд. при М-ве вн. дел П.Н. Батюшковым СПб. 1887.

${ }^{41}$ ОР РНБ, ф. 52, ед. хр. 94, лл. 8-8v. 
jest postać Daniela Romanowicza ${ }^{42}$, księcia Rusi Halickiej i przez krótki okres „króla” Galicji. Daniel został koronowany przez legata papieskiego w 1253 lub 1254 roku w Drohiczynie, w miejscowej cerkwi. Sojusz cerkwi i papiestwa, zapoczątkowany wówczas w ramach próby stworzenia koalicji przeciw Tatarom, był jednak krótkotrwały i nie przyniósł oczekiwanych skutków. Właśnie „Danielowi Romanowiczowi, założycielowi Chełma i jego biskupstwa"43 A.S. Pietruszewicz, znany galicyjski filolog i historyk słowiańszczyzny, należący do ruchu moskalofilów, poświęcił swój zbiór esejów o najważniejszych przedstawicielach Kościoła greckokatolickiego w Chełmie. W latach postyczniowych przedstawiciele chełmskiego duchowieństwa zwrócili uwagę na postać Daniela m.in. w kontekście zlokalizowania miejsca jego pochówku. Według przekazów tradycyjnych władca ruski miał zostać pochowany w dawnym soborze, który uległ zniszczeniu już po jego śmierci. Powstała więc konieczność odnalezienia „,bezcennych” szczątków - wedle słów Aleksandra Budiłowicza, który zachęcał archeologów do rozkopywania podłogi pod soborem - w celu wystawienia ich do uczczenia przez prawosławnych wiernych chełmskiej diecezji ${ }^{44}$. Podobnie jak ikona Matki Boskiej Chełmskiej także relikwie ruskiego księcia były symbolem wspólnoty, przedmiotem czci oraz kultu czyniącego z Daniela archetyp świętego, bezpośrednio nawiązujący do świętości Włodzimierza Wielkiego, co symbolicznie wskazywało na głęboką więź między władzą duchowną a świecką średniowiecznej Rusi.

${ }^{42}$ O Danielu Romanowiczu zob. np. Н.Ф. Котляр, Даниил, князь Галицкий, Алетейя Санкт-Петербург 2008; D. Dąbrowski, Daniel Romanowicz król Rusi (ok. 1201-1264). Biografia polityczna, Wydawnictwo Avalon, Kraków 2012; A. Gil, A. Wawryniuk, H. Bazhenova (red.), Daniel Romanowicz i jego czasy, „Rocznik Instytut Europy Środkowo-Wschodniej" 6/2014.

${ }^{43}$ А.С. Петрушевич, Холмская епархия и святители ею, тип.Ставропиг. ин-та, Львов 1867.

${ }^{44}$ A.С. Будилович, Чудотворная икона, s. 72. Raport z wykopalisk na górce chełmskiej można znaleźć w artykule napisanym przez kustosza Muzeum archeologicznego w Chełmie: Ф.В. Кораллов, Раскопки в г. Холме на высокой соборной горке в 1911 г., „Братская Беседа” 18/1911, s. 2. 
Danielowi Halickiemu poświęcił obszerne studium N.I. Pawłiszczew, dyrektor i założyciel w 1864 r. „Warszawskiego dziennika”, oficjalnej rosyjskiej gazety w Warszawie. Był on także kierownikiem Wydziału Periodyków, organu nadzorowania prasy krajowej i zagranicznej w Królestwie Polskim ${ }^{45}$. Pawłiszczew pracował w Polsce długo, ponad 30 lat; przyjechał do Kongresówki w 1831, wszedł w skład rosyjskiego rządu tymczasowego po powstaniu listopadowym. Był ponadto członkiem Rady Oświecenia Publicznego i nauczycielem historii, geografii i statystyki w szkołach Królestwa oraz autorem studiów z historii i geografii rosyjskiej i polskiej ${ }^{46}$.

Tekst poświęcony księciu Danielowi, który ze względu na potrzeby poszerzania zasięgu narracji narodowotwórczej został przedrukowany także w „Chełmskim Kalendarzu Greckokatolickim” w latach 1869-187147, opierał się głównie na Kronice halicko-wołyńskiej i opowiadał żywot Daniela od samego dzieciństwa, kiedy to, po śmierci ojca, Romana, dziecko zostało powierzone przez matkę opiece najpierw króla Węgier, a następnie króla Polski Leszka Białego. Ten ostatni był skoligacony z rodziną Romanowiczów. Ziemia halicka, w okresie rozbicia dzielnicowego Rusi Kijowskiej i bratobójczych walk pomiędzy Rurykowiczami, znalazła się w centrum uwagi z racji korzystnego położenia na skrzyżowaniu szlaków handlowych z Polską i Królestwem Węgier. Walka o jej kontrolę toczyła się więc pomiędzy Rurykowiczami, którzy uważali się za prawowitych dziedziców tronu halickiego, miejscowymi

${ }^{45}$ M. Rolf, Rzady imperialne w Kraju Nadwiślańskim. Królestwo Polskie i cesarstwo rosyjskie (1864-1915), przeł. W. Włoskowicz, WUW, Warszawa 2016, s. 137.

${ }^{46} \mathrm{~Np}$. Польская история в виде учебника, Казенная тип., Варшава 1843; Исторический атлас России, тип. Стромбовского, Варшава 1845 , oraz artykuł Поездка в Червонную Русь („Северная Пчела” 1844, 287 (с. 1147-1148), 288 (с. 1151-1152), 289 (1155-1156), 290 (1159-1160)), w którym autor zlokalizował starożytne miasto Czerwień w miejscowości Czermno w guberni lubelskiej.

${ }^{47}$ Н. Павлищев, Даниил, король русский, „Холмский греко-униатский Месяцеслов на 1869 год”, Варшава 1869, s. 93-125; „Холмский греко-униатский Месяцеслов на 1870 год”, Варшава 1870, s. 1-43; „Холмский греко-униатский Месяцеслов на 1871 год”, Варшава 1871, s. 1-24. 
bojarami oraz Polską i Węgrami. Szczegółowe przedstawienie biografii Daniela miało w intencji Pawłiszczewa służyć pochwale czynów księcia - obrońcy Rusi zachodniej przed wrogami: Polakami, Węgrami, pogańskimi Litwinami, przed najazdami tatarskimi oraz próbami nawrócenia przeprowadzanymi przez Kościół rzymskokatolicki, przed propozycją zawarcia unii z Rzymem wysuniętą w połowie XIII w. i przed systematycznym katolickim prozelityzmem wobec wyznawców prawosławia ${ }^{48}$. Daniel, jak zauważał Pawłiszczew, stał się faktycznie „królem” Rusi - co zresztą zostało uwypuklone w samym tytule eseju - dzięki wyżej wspomnianej koalicji antytatarskiej zawartej z papieżem i następnie koronacji w Drohiczynie w 1253 lub 1254 r. Jednak nie przystał na papieską propozycję unii kościelnej, dzięki czemu zostało zachowane pierwotne prawosławie ziem ruskich"49. W dalszej części dowodzenia Pawłiszczew kładł nacisk na decyzję Daniela o założeniu Chełma i podniesieniu go do rangi stolicy księstwa halicko-włodzimierskiego i centrum prawosławnej eparchii ${ }^{50}$. Co znaczące, w biografii Daniela ważne miejsce zajmuje motyw polowania. Jej autor wykorzystuje tu opowieść ze wspomnianej już Kroniki halicko-wołyńskiej która podaje, że podczas łowów książę zatrzymał się na odpoczynek na malowniczym wzgórzu, przykrytym lasem. Tu postanowił założyć gród - przyszłą stolicę swego księstwa. Warto podkreślić zbieżność mitu polowania, leżącego u podstaw założenia zarówno miasta Chełma, jak i Stołpieńskiej wieży (rys. 5) $)^{51}$.

\footnotetext{
${ }^{48}$ Por. Н. Павлищев, Даниил, король русский, „Холмский греко-униатский Месяцеслов на 1870 год”, s. 39-40.

${ }^{49}$ Tamże, s. 12-13.

${ }^{50}$ Tamże, s. 25-26.

${ }^{51}$ O praktyce łowów jako o rozpowszechnionym zajęciu władców Rusi zob. D. Dąbrowski, Król Rusi Daniel Romanowicz. O ruskiej rodzinie książęcej, społeczeństwie i kulturze w XIII w., Wydawnictwo Avalon, Kraków 2016, s. 262-264; zob. też Д. Иловайский, Даниил Романович Галичкий и начало Холма, [w:] Памятники русской старины в западных губерниях, Вып. 7: Холмская Русь, s. 1-13. Mit polowania w historii Rosji uwieczniony został w publikacji Nikołaja Kutiepowa z 1896 roku pod tytułem Polowanie na Rusi Wielkich Książat, Carów i Imperatorów, powstałej z woli Imperatora Aleksandra III. Dzieło ukazało się w Petersburgu w latach 1896-1911 w 4
} 


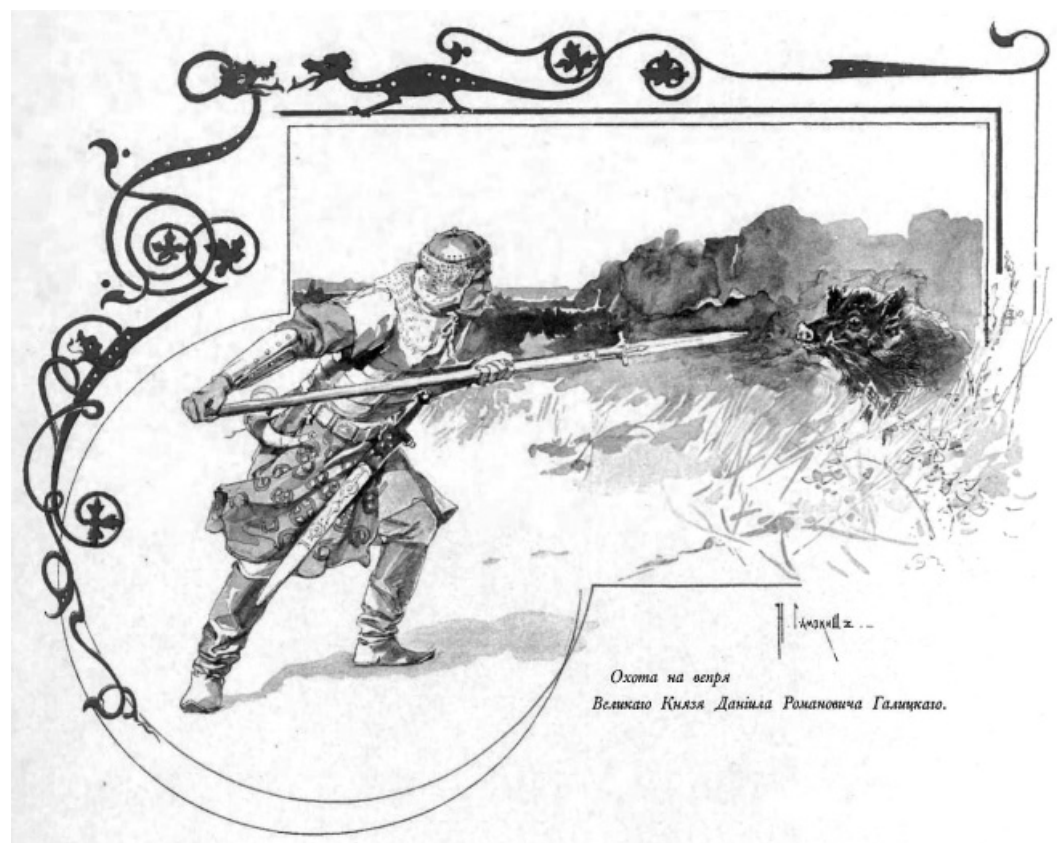

Rys. 5: Daniel Romanowicz (źródło: Великокняжеская и царская охота на Руси с X nо XVI век, исторический очерк Николая Кутепова, Экспедиция заготовления гос. бумаг, Санкт-Петербург. 1896, ze zbiorów cyfrowych Rosyjskiej Biblioteki Państwowej)

Pawłiszczew oddał swój hołd czynom Daniela uwagą o tryumfie prawosławia, oraz o randze, do której z czasem duchowieństwo prawosławne zostało podniesione. W tej części świata ruskiego Daniel był postrzegany jako ojciec państwowości ruskiej i prawosławia; w zbiorowej pamięci współczesnych „Rosjan” ziemi chełmskiej jego postać miała przetrwać jako mityczny pierwowzór, nośnik władzy zarówno świeckiej, jak i sakralnej, w duchu staroruskiej symfonii władzy.

tomach. Daniel jest tu nazwany „znakomitym księciem-myśliwym” i przedstawiony pędzlem Nikołaja Samokisza, podczas łowów na dzika. Zob. Великокняжеская и изарская охота на Руси с X по XVI век, исторический очерк Николая Кутепова, Экспедиция заготовления гос. бумаг, Санкт-Петербург 1896, s. 106-108. 


\section{Uwagi końcowe}

Opisany tutaj proces rosyjskiego unarodowienia ruskich chłopów był możliwy dzięki inicjatywie intelektualistów (historyków, filologów) oraz duchowieństwa prawosławnego działającego na peryferii imperium i polegał na różnorakich działaniach zmierzających do odsłonięcia śladów („miejsc pamięci”) dawnej świetności rosyjskiej stariny w celu prospektywnej rekonstrukcji utraconej wspólnoty (,środowiska”). Odkrycie pierwotnej rosyjskości ziemi chełmskiej, a co za tym idzie, traktowanie chłopa jako nośnika najważniejszych wartości podstawowych - narodowych i wyznaniowych było w przekonaniu wyższych rosyjskich urzędników dziełem przede wszystkim przedstawicieli inteligencji peryferiów, którzy kierowali się inspiracjami słowianofilskimi i panslawistycznymi. W kręgach dworskich patrzono z nieufnością na taki program (którego źródła sięgały okresu uwłaszczenia chłopów), widząc w nim ruch populistyczny, zagrażający tradycyjnej równowadze pomiędzy dworem i środowiskami konserwatywnymi (dworianstwo). Żądania zwolenników unarodowienia Rusinów można ująć - wedle znanej kategoryzacji Tilly'ego ${ }^{52}$ - jako sui generis wyraz nacjonalizmu „bottom-up”. Jeżeli taki oddolny nacjonalizm uważany jest za rezultat działalności elity, stojącej po stronie uciemiężonej przez narodowość panującą wspólnoty innej narodowości, to w przypadku Chełmszczyzny elita peryferyjna chroniła ludność uważaną za rosyjską przed obcą (polską i katolicką), a nie przed panującą elitą. W dodatku elita promująca asymilację narodową skłaniała się ku ideologii narodowościowej o znacznie większym stężeniu etnowyznaniowym niż oficjalna narodowość. Ta ostatnia wciąż była odbiciem słynnej triady Siergieja Uwarowa, wedle której narodowość i religia miały dla imperium znaczenie raczej funkcjonalne niż celowe ${ }^{53}$.

${ }^{52}$ C. Tilly, The state of nationalism, „Critical Review” 10/1996, s. 299-306. Por. też The Formation of National States in Western Europe, Edited by Charles Tilly, Princeton, Princeton University Press, 1975.

${ }^{53}$ А. Зорин, Заветная Триада. Меморандум С.С. Уварова 1832 года и возникновение доктрины «православие - самодержавие - народность», [w:] tegoż, 
Oznacza to, że ideologia „peryferyjna” nie była całkowicie tożsama z oficjalną ideologią nadaną „,z góry” (top-down nationalism). Dlatego można pokusić się o stwierdzenie, że proces unarodowienia kresów imperium, promowany po $1863 \mathrm{r}$. przez młodsze pokolenie intelektualistów oraz duchowieństwo wyprzedzał $\mathrm{i}$ - w pewnej mierze - inspirował elitę petersburską do ewolucji polityki państwowej w stronę nacjonalizacji wielonarodowego państwa.

\section{Bibliografia}

Angé O., Berliner D., Anthropology of nostalgia - anthropology as nostalgia [w:] tegoż (eds.), Anthropology and Nostalgia, Berghahn Books, New York-Oxford 2015, s. 1-15.

Aronsson P., Elgenius G. (eds.) National Museums and Nation-Building in Europe 1750-2010: Mobilization and Legitimacy, Continuity and Change, Routledge, New York 2015.

Assmann A., Cultural Memory and Western Civilization: Functions, Media, Archives, Cambridge University Press, New York 2011.

Assmann J., Collective memory and cultural identity, „New German Critique” 65/1995, s. 125-133.

Atia N., Davies J., Nostalgia and the shapes of history, „Memory Studies” 3(3)/2010, s. 181-186.

Bellentani F., Panico M., The meanings of monuments and memorials: toward a semiotic approach, „Punctum” 2(1)/2016, s. 28-46.

Berliner D., The abuses of memory: Reflections on the memory boom in anthropology, ,, Anthropological Quarterly” 78(1)/2005, s. 197-211.

Boym S., Nostalgia i postkomunistyczna pamięć, [w:] F. Modrzejewski, M. Sznajderman (red.), Nostalgia. Eseje o tęsknocie za komunizmem, Czarne, Wołowiec 2002, s. 270-301.

Boym S., The Future of Nostalgia, Basic Books, New York 2001.

Budilovich A.S., Chudotvornaya ikona Presvyatoy Bogoroditsy w g. Kholme [w:] Pamyatniki russkoy stariny $v$ zapadnykh guberniyakh, izdavayemye s vysochajshego soizvoleniya P.N. Batiushkovym, Wyp. 7: Kholmskaya Rus' (Lublinskaya i Sedletskaya gub., Varshavskogo General-Gubernatorstva),

Кормя двуглавого орла... Литература и государственная идеология в России в последней трети XVIII - первой трети XIX века, Новое Литературное Обозрение, Москва 2004, s. 337-374. 
Petersburg 1885, s. 63-112 [Будилович А.С., Чудотворная икона Пресвятой Богородицы в г. Холме [в:] Памятники русской старины в западных губерниях, издаваемые с высочайшего соизволения П.Н. Батюшковым, Вып. 7: Холмская Русь (Люблинская и Седлецкая губ., Варшавского Генерал-Губернаторства), М-во внутр. дел, Санкт-Петербург 1885, c. 63-112].

А. Будилович, Холмская чудотворная икона Божией Матери, тип. Варшавскаго учебного округа: издание Холмскаго Св. Богородицкаго братства, Варшава 1892 Buko A., Zagadka pogranicza. Zespót wieżowy w Stotpiu, „Archeologia Żywa” 3 (33)/2005, s. 44-49.

Buko A. (red.), Zespół wieżowy w Stotpiu: badania 2003-2005, IAE PAN, IA UW, Warszawa 2009.

Kholmskij Bratchik [Lebedincev F.G.], (recenzja) Gorod Kholm i jego drevniaya sviatynya - chudotvornaya ikona Bozjiyey Matieri, Izdanije Kholmsko-bogorodickogo pravoslavnogo bratstva. Varshava. 1882, „Kiyevskaya Starina” 1883, 3, s. 653-657 [Холмский Братчик [Ф.Г. Лебединцев], (recenzja) Город Холм и его древняя святыня - чудотворная икона Божией Матери, Издание Холмско-богородицкого православного братства. Варшава, «Киевкая старина» 3/1883, с. 653-657].

Chruscevich G.K., Belavinskaya i Stolpenskaya bashni pod Kholmom, [w:] Pamiatniki russkoj stariny $w$ zapadnykh guberniyakh, izdavajemyje s wysochajshego soizvoleniya P.N. Batiushkowym, Vyp. 7: Kholmskaja Rus' (Lublinskaya i Sedletskaya gub., Varshavskogo General-Gubernatorstva), Petersburg 1885, s. 45-62 [Хрусцевич Г.К., Белавинская и Столпьенская башни под Холмом [w:] Памятники русской старины в западных гберниях, издаваемые с высочайшего соизволения П.Н. Батюшковым, Вып. 7, М-во внутр. дел, Санкт-Петербург 1885, с. 45-62].

Dąbrowska M., Głuszkowski P. (red.), Mikołaj Karamzin i jego czasy, „Studia Rossica"XXIV/2017.

Dąbrowski D., Daniel Romanowicz król Rusi (ok. 1201-1264). Biografia polityczna, Wydawnictwo Avalon, 2012.

Dąbrowski D., Król Rusi Daniel Romanowicz. O ruskiej rodzinie książęej, społeczeństwie i kulturze w XIII w., Wydawnictwo Avalon, Kraków 2016.

Den Boer P., Loci memoriae-Lieux de mémoire, [w:] A. Erll, A. Nuenning., de Gruyter W. (eds.), Cultural Memory Studies. An International and Interdisciplinary Handbook, de Gruyter, Berlin-New York 2008, s. 19-25.

Dmitruk S., Ks. Aleksander Budiłowicz (1845 - po 1914) - prawosławny duchowny z Grodzieńszczyzny $w$ diecezji chetmskiej, [w:] J. Jurkiewicz (red.), Białorusini-Historia i kultura, Expol, Szreniawa 2010. 
Je.M. [Modest, yepiskop], Kholmskaya pravoslavnaya eparkhiya. Gorod Kholm, „Kholmsko-Varshavskiy eparkhial 'nyy Viestnik” 1884, nr 4, s. 53-59 [E.M. [Модест, епископ], Холмская парвославная епархия. Город Холм, „Холмско-Варшавский епархиальный вестник" 4/1884, с. 53-59].

Gerbachevskij F., Russkije drevnosti i pamiatniki pravoslaviya Kholmsko-Podlashskoy Rusi (Lublinskoy i Sedleckoy gubiernii), Varshava 1892 [Гербачевский Ф., Русские древности и памятники православия Холмско-Подляшской Руси (Люблинской и Седлецкой губернии), Сочинение и издание любителя Русской Старины священ. Федора Гербачевского, Варшава 1892].

Gil A., Geneza nowożytnego kultu ikony Matki Boskiej Chetmskiej [в:] Wolinska ikona: doslidzhennya ta restavratsiya, vip. 10, Materijaly X mizhnarodnoy naukovoy konferentsii, Lutsk 2003, s. 106-112 [Волинська ікона: дослідження та реставращія, вип. 10, Матеріяли Х міжнародної наукової конференuүï, Луцьк 2003, с. 106-112].

Gil A., Wawryniuk A., Bazhenova H. (red.), Daniel Romanowicz i jego czasy, „Rocznik Instytut Europy Środkowo-Wschodniej” 6/2014.

Halbwachs M., Les cadres sociaux de la mémoire, Albin Michel, Paris 1994 [1925].

Ilovayskiy D., Daniil Romanovich Galitskiy i nachalo Kholma [w:] Pamiatniki russkoy stariny $w$ zapadnykh guberniyakh, izdavajemyye $s$ vysochajshego soizvoleniya P.N. Batiushkowym, Vyp. 7: Kholmskaya Rus' (Lublinskaya i Sedletskaya gub., Varshavskogo Genera-Gubernatorstva), Petersburg 1885, s. 1-13 [Д. Иловайский, Даниил Романович Галицикии и начало Холма [w:] Памятники русской старины в западных губерниях, издаваемые с высочайшего соизволения П.Н. Батюшковым, Вып. 7: Холмская Русь (Люблинская и Седлецкая губ., Варшавского Генерал-Губернаторства), М-во внутр. дел, Санкт-Петербург 1885, с. 1-13].

Isnenghi M., I luoghi della memoria. Simboli e miti dell'Italia unita, Laterza, Bari 1996.

Isnenghi M., Italian luoghi della memoria [w:] A. Erll, A. Nuenning., de Gruyter W. (eds.), Cultural Memory Studies. An International and Interdisciplinary Handbook, de Gruyter, Berlin-New York 2008, s. 27-35.

Kabzińska I. Pamięć, nostalgia i zazdrość o „,dawne, dobrze czasy”. Narracje i różne rodzaje pamięci, „Etnografia Polska» L(1-2)/2006, s. 177-196.

Kindt J., On Nostalgia, „Meanjin” 77(2)/2018, s. 199-205.

Korallov F.V., Raskopki w g. Kholme na vysokoy sobornoy gorke v 1911 g., „Bratskaja Biesieda" 18/1911, s. 2 [Кораллов Ф.В., Раскопки в г. Холме на высокой соборной горке в 1911 г., „Братская Беседа” 18/1911, с. 2].

Kotlar N.F., Daniil, knaz' Galitskiy, Peterburg 2008 [Котляр Н.Ф., Даниил, князь Галицикий, Алетейя, Санкт-Петербург 2008]. 
Kryzhanovskiy JE.M., Retsenziya na sochineniye magistra sviashchennika Aleksandra Budilovicza: Russkaya pravoslavnaya starina $w$ Zamostye, Varshava 1885 goda. Otchot o tridsatom prisuzhdienii nagrad grafa Uvarova, Petersburg 1889 [Крыжановский Е.М., Рецензия на сочинение магистра священника Александра Будиловича: Русская православная старина в Замостье, Варшава 1885 года. Отчет о тридцатом присуждении наград графа Уварова, тип. Акад. наук, Санкт-Петербург 1889].

Lebiedincev F.G., Otkrytiye w g. Kholme russkoy siedmiklassnoj gimnazii i piedagogicheskikh kursov, „Kiyevskiye eparchial'nyye viedomosti” 21/1865, s. 801-816 [Лебединцев Ф.Г., Открытие в г. Холме русской седмиклассной гимназии и педагогических курсов, „Киевские епархиальные ведомости" 21/1865, с. 801-816].

Labyncev Ju. A., Schavinskaya L.L., Zhyvaja drevnost': litieraturnaya tradiciya kul'ta ikony Bogomatieri Kholmskoy nashych dniey, „Drevnaya Rus'. Voprosy mediyevistiki” 2(8)/2002, s. 14-25 [Лабынцев Ю.А., Щавинская Л.Л., Живая древность: литературная традиция культа иконь Богоматери Холмской наших дней, „Древная Русь. Вопросы медиевистики” 2(8)/2002, c. 14-25].

Laptieva L.P., Istoriya slavianovedeniya w Rossii w XIX veke, Moskva 2005 [Лаптева Л.П., История славяноведения в России в XIX веке, Индрик, Москва 2005].

Łuczewski M., Odwieczny naród. Polak i katolick w Żmiącej, WN UMK, Toruń 2012.

Mart K., «Phoenix» Jakuba Suszy źródtem do badań ikonografii Matki Boskiej Chetmskiej, „Series Byzantina” 2/2004, s. 189-201.

Momigliano A., Ancient History and the Antiquarian, „The Journal of the Warburg and Courtauld Institutes" 13(3/4)/1950, s. 285-315.

Nacional'na biblioteka Ukrajiny imeni V.I. Vernads'koho, Instytut rukopysu (IR NBUV), f. I (Lebiedincev Fieofan Gavrltovich), n. 11169, Matierialy k biografii F.G. Lebiedinceva [Національна бібліотека України імені В. I. Вернадського, Інститут рукопису (ІР НБУВ), ф. I (Лебединцев Феофан Гаврилович), н. 11169, Материаль к биографии Ф.Г. Лебединцева].

Nikulin D., The Concept of History, Bloomsbury Academic, New York 2017.

Nora P., Between Memory and History: Les Lieux de Mémoire, „Representations” 26/1989, s. 7-24.

Nora P., Les Lieux de mémoire, Gallimard, Paris, 3 tomes: t. 1 La République (1 vol., 1984), t. 2 La Nation (3 vol., 1986), t. 3 Les France (3 vol., 1992).

Nowak A., Metamorfozy. Imperium Rosyjskiego 1721-1921. Geopolityka, ody i narody, Wydawnictwo Literackie, Kraków 2018. 
Najt N., Nauka, Impieriya i narodnost'. Etnografija v Russkom gieograficheskom obshchestve, [v:] Rossijskaya impieriya v zarubiezhnoy istoriografii. Raboty poslednikh let: Antologiya, Sost. P. Viert, P.S. Kabytov, A.I. Miller, Moskva 2005, s. 155-198 [Найт Н., Наука, империя и народность: этнография в Русском географическом обществе, [в:] Российская империя в зарубежной историографии. Работы последних лет: Антология, Новое издательство, Москва 2005, с. 155-198].

Ливотов, Е.В., Краткое сказание о Холмской чудотворной иконе божией матери и бывших от нее чудесах, Холмск. св. Богородиц. братство, Холм 1899

O.P., Zamechatel'nykh prazdnikv g. Kholme, Kiyevskaya Starina” [О.П., Замeчательный праздник в г. Холме, „Киевская старина”] 11/1886, s. 561-567.

Otdel Rukopisey Rossiyskoy Nacional'noy Bibliotieki (OR RNB), f. 52, jed. Chr. 94 (Ob. izdaniyakh Ministerstva Vnutriennykh Del po Zapadnomu Krayu s 1863 po 1889 gody. 22 noyabrya 1889) [Отдел Рукописей Российской Нфциональной Библиотеки, ф. 52, ед. хр. 94 (Об изданиях Министерства Внутренних Дел по Западному Краю с 1863 по 1889 годы. 22 ноября 1889)].

Otdel Rukopisey Rossiyskoy Nacional'noy Bibliotieki (OR RNB), f. 52, jed. chr. 132 (Budilovicz Aleksandr Sergieyevivz sviashch. Pis'ma P.N. Batiushkovu) Отдел Рукописей Российской Нфциональной Библиотеки, ф. 52, ед. хр. 132 (Будилович Александр Сергеевич свящ. Письма П.Н. Батюшкову)].

Pamyatniki russkoy stariny $w$ zapadnykh guberniyakh, izdavayemyye s vysochayshego soizvoleniya P.N. Batiushkowym, Vyp. 7: Kholmskaya Rus' (Lublinskaya i Syedletskaya gub., Varshavskogo General-Gubernatorstva), Petersburg 1885 [Памятники русской старины в западных губерниях, издаваемые с высочайшего соизволения П.Н. Батюшковым, Вып. 7: Холмская Русь (Люблинская и Седлецкая губ., Варшавского Генерал-Губернаторства), М-во внутр. дел, Санкт-Петербург 1885].

Pamyatniki russkoy stariny w zapadnykh guberniyakh, izdavayemyye s vysochayshego soizvoleniya P.N. Batiushkowym, Vyp. 8: Kholmskaya Rus' (Lublinskaya i Syedletskaya gub., Varshavskogo General-Gubernatorstva), Petersburg 1885 [Памятники русской старины в западных губерниях, издаваемые с высочайшего соизволения П.Н. Батюшковым, Вып. 8: Холмская Русь (Люблинская и Седлецкая губ., Варшавского Генерал-Губернаторства), М-во внутр. дел, Санкт-Петербург 1885].

Pavlishchev N., Pol'skaya istoriya v vide uchebnika [Павлищев Н., Польская история в виде учебника, Казенная тип., Варшава 1843].

Pavlishchev N., Istoricheskiy atlas Rossii, Petersburg 1845 [Исторический amлас России, тип. Стромбовского, Варшава 1845]. 
Pavlishchev N., Poyezdka w Chervonnuyu Rus', „Seviernaya Pchela” [Павлищев Н., Поездка в Червонную Русь, „Северная Пчела” 1844, 287 (с. 11471148), 288 (c. 1151-1152), 289 (1155-1156), 290 (1159-1160) ].

Pavlishchev N., Daniil, korol' russkiy, „Kholmskiy grieko-uniatskiy Mesyatseslov na 1869 god", Varshava 1869, s. 93-125 [Павлищев Н., Даниил, король русский, “Холмский греко-униатский Месяцеслов на 1869 год”, Варшава 1869 , с. 93-125].

Pavlishchev N., Daniil, korol' russkiy, „Kholmskiy grieko-uniatskiy Mesyatseslov na 1870 god", Varshava 1870, s. 1-43 [Павлищев Н., Даниил, король русский, [w:] „Холмский греко-униатский Месяцеслов на 1870 год”, Варшава 1870 , с. 1-43].

Pavlishchev N., Daniil, korol' russkiy, „Kholmskiy grieko-uniatskiy Mesyatseslov na 1871 god” [Павлищев Н., Даниил, король русский, „Холмский греко-униатский Месяцеслов на 1871 год”, Варшава 1871, с. 1-24].

[Petrov N.I.], Kholmskaya Rus'. Istoricheskiye sud'by russkogo zarubiezzhya, izd. P.N. Batiushkovym, Petersburg 1887 [[Петров Н.И.], Холмская Русь. Исторические судьбы русского зарубежья, Изд. при М-ве вн. дел П.Н. Батюшковым , Санкт-Петербург 1887].

А.С. Петрушевич, Холмская епархия и святители ею, тип. Ставропиг. ин-та, Львов 1867

Piccin M., La politica etno-confessionale zarista nel Regno di Polonia: la questione uniate di Cholm come esempio di nation-building russo (1831-1912), PhD Dissertation, Università Ca' Foscari di Venezia, Venezia 2011.

Piccin M., Geografie wyobrażone rosyjskiego nacjonalizmu: gubernie zachodnie Imperium $i$,Ruś Chetmska” między tradycja a nowoczesnościa myśli narodowej, [w:] Przypominać zapomniane, odkrywać nieznane. Polskie losy - Kościót - Syberia - Rosja (XIX-XX w.): studia ofiarowane Profesorowi Eugeniuszowi Niebelskiemu w 70. rocznicę urodzin, red. nauk. Anna Barańska, Lublin 2019, s. 205-224

Pickering M., Keightley E., The Modalities of Nostalgia, „Current Sociology” 54/2006, s. 919-941.

Pomian K., Zbieracze i osobliwości. Paryż-Wenecja XVI-XVIII wiek, przeł. A. Pieńkos, słowo/ obraz terytoria, Gdańsk 2012.

Przeciszewska M.M., Tygodnik ilustrowany „, Oświata” jako narzędzie formowania ,, cesarskiego chtopa” w Królestwie Polskim w latach 1900-1905, „Rocznik Biblioteki Narodowej" XLVI/2015, s. 197-219.

Przeciszewska M.M., ,, Tworzenie Rosjan”. Narodowotwórcza funkcja wybranych publikacji Bractwa Przenajświętszej Bogurodzicy w Chetmie (1884-1915), „Rocznik Biblioteki Narodowej”XLVIII/2017, s. 347-372. 
Put' moyey zhyzni. Vospominaniya Mitropolita Evlogiya. Izlozhennyye po jego rasskazam T. Manuchinoj, Paryzh 1947 [Путь моей жизни. Воспоминания Митрополита Евлогия. Изложеннье по его рассказам Т. Манухиной, YMCA-PRESS, Париж 1947].

Ricoeur P., Pamięć, historia, zapomnienie, przeł. J. Margański, Universitas, Kraków 2007.

Rolf M., Rządy imperialne w Kraju Nadwiślańskim. Królestwo Polskie i cesarstwo rosyjskie (1864-1915), przeł. W. Włoskowicz, WUW, Warszawa 2016.

Srieznevskiy I.I., Kamenetskaya vezha, [v:] Onże, Svedeniya i zametki o maloizvestnykh i neizvestnykh pamyatnikakh, vyp. I, Petersburg 1867, s. 8-9 [И.И. Срезневский, Каменецкая вежа, [w:] Онже, Сведения и заметки о малоизвестных и неизвестных памятниках, вып I, тип. Императорской Академии Наук, С.-Петербург 1867 , с. 8-9].

Stefański J., Z dziejów kultu obrazu Matki Boskiej Chetmskiej, „Nasza Przeszłość. Studia z dziejów Kościoła i kultury katolickiej w Polsce” 66/1986, s. 159-190.

Stolpy ili vezhy pod Kholmom (Iz zapisok P. Revyakina), „Kholmskiy greko-uniatskiy Mesyaceslov na 1868 god" Varshava 1868, s. 129-142 [Столпь или вежи под Холмом (Из записок П. Ревякина), „Холмский греко-униатский Месяцеслов на 1868 год” Варшава 1868, с. 129-142].

Strada V., EuroRussia. Letteratura e cultura da Pietro il Grande alla rivoluzione, Laterza, Roma-Bari 2005.

Szabaciuk A., ,Rosyjski Ulster». Kwestia chetmska w polityce imperialnej Rosji $w$ latach 1863-1915, Wydawnictwo KUL, Instytut Europy Środkowo-Wschodniej, Lublin 2013.

Tamm M., Beyond History and Memory: New Perspectives in Memory Studies, „History Compass” 11(6)/ 2013, s. 458-473.

Tilly C., The state of nationalism, „Critical Review” 10/1996, s. 299-306.

The Formation of National States in Western Europe, Edited by Charles Tilly, Princeton, Princeton University Press, 1975.

W.M., Gorod Kholm i yego drevnyaya svyatynya chudotvornaya ikona Bozhijey Materi, Izdaniye Kholmsko-bogoroditskogo pravoslavnogo bratstva, Varshava 1882 [B.M., Город Холм и его древняя святыня чудотворная икона Божией Матери, Издание Холмско-богородиикого православного братства, Варшава 1882].

E. Weber, Da contadini a francesi. La modernizzazione della Francia rurale 1870-1914, Il Mulino, Bologna 1989

Weeks Th.R., The «End» of the Uniate Church in Russia: The Vossoedinenie of 1875, „Jahrbücher für Geschichte Osteuropas” 44(1)/1996, s. 28-40. 
Velikoknazheskaya i tsarskaya okhota na Rusi s X po XVI vek, istoricheskiy ocherk Nikolaya Kutepova, Petersburg 1896 [Великокняжеская и иарская охота на Руси с X по XVI век, исторический очерк Николая Кутепова, Экспедиция заготовления гос. бумаг, Санкт-Петербург 1896].

Wertsch J.V., Collective Memory [w:] Boyer P., Wertsch J. V. (eds.), Memory in Mind and Culture, Cambridge University Press, New York 2009, s. 117-137.

Whitling F., Damnatio memoriae and the Power of remembrance. Reflections on Memory and History [w:] Pakier M., Stråth B. (eds.), A European Memory? Contested Histories and Politics of Remembrance, Berghahn Books, New York-Oxford 2010, s. 87-97.

Wiercieński H., Ziemia Chetmska i Podlasie. Rys historyczny i obraz stanu dzisiejszego, Gebethner i Wolff, Warszawa 1920.

Winter J., Historians and Sites of Memory [w:] Boyer P., Wertsch J. V. (eds.), Memory in Mind and Culture, Cambridge University Press, New York 2009, s. $252-268$.

Winter J., The Generation of Memory: Reflections on the “Memory Boom”, „Contemporary Historical Studies, Archives \& Social Studies: A Journal of Interdisciplinary Research" 1(0)/2007, s. 363-397.

Zorin A., Zavetnaya Tryada. Memorandum S.S. Uvarova 1832 goda i vozniknoveniye doktriny "pravosvaviye - samoderzhaviye - narodnost'», [v:] Onże, Kormya dvuglavogo orta... Literatura i gosudarstvennaya ideologiya v Rossii v posledney treti XVIII - pervoy treti XIX veka, Moskwa 2004, s. 337-374 [Зорин А., Заветная Триада. Меморандум С.С. Уварова 1832 года и возникновение доктринь «православие - самодержавие - народность», [в:] tegoż, Кормя двуглавого орла... Литература и государственная идеология в России в последней трети XVIII - первой трети XIX века, Новое Литературное Обозрение, Москва 2004, с. 337-374].

\section{Lieux de Mémoire on the Polish-Ruthenian Frontier: the Case of Chełm Region (after 1863)}

This article analyses the nationalization process among the Ruthenian population of Chełm Region in the period after the January Uprising. From the 1850s, Russian intellectuals of the Slavophile and Pan-Slavic orientation began to perceive the eastern frontier of the Kingdom of Poland as indigenously Russian land. These areas, as a result of the Brest union, were for a few centuries strongly influenced by Polish culture and the Roman Catholic Church. The Russian authorities sought to build Russian national and Orthodox religious consciousness among the local Ruthenian people using tools 
Matteo Piccin, Lieux de Mémoire na pograniczu polsko-ruskim...

(lieux de mémoire) such as museums, newspapers and apologetics, both scientific and popular, directed towards both schools and the common people. Further tools included the celebration of state and church anniversaries, the erection of monuments, and the renovation of churches in the Byzantine style. Most of these lieux de mémoire were created, invented, or reworked to serve the nation-state. This "Nostalgic experience" was a way of shaping and directing historical consciousness. Russian national State was thus conceived, establishing and legitimating itself as a great regenerative process founded on, and made of, memory. The ideology of government-supporting intellectuals and clergy in the borderlands of the empire can be defined as primordialism, according to which the nation is defined as a group based on a perpetual community of origin, religion and morality, as well as attachment to the land of fathers. The practice of such periphery nationalism differed significantly from the famous doctrine of official nationality, formulated by Sergey Uvarov in the 1830s. Nationalist concerns from the borderlands were one of the factors that led to the evolution of the St. Petersburg elite's policy towards nationalization of the Romanov Empire.

key wo rd s: nostalgia, memory, nationalism, Russian Empire, Kingdom of Poland 
